\title{
THE USES OF MYTH AND RITUALS AS COMMUNICATION STRATEGIES FOR ENVIRONMENTAL PRESERVATION BY KRATON NGIYOM IN SEKARALAS AND SEKARPUTIH VILLAGES
}

\author{
Rizaldi Parani ${ }^{1}$, Brigitta Berliana ${ }^{2}$, Liza Diniarizky Putri ${ }^{3}$, Annisarizki $^{4}$, Abdul Malik $^{5}$ \\ Department Communication, Pelita Harapan University ${ }^{12}$ \\ Department Communication, Serang Raya University ${ }^{345}$ \\ rizaldi.parani@uph.edu¹, gitaberliana7@gmail.com², i_jupri@rocketmail.com³* \\ annisarizzkii@gmail.com ${ }^{4}$, kangdoel2002@gmail.com ${ }^{5}$
}

\begin{abstract}
Kraton Ngiyom is a non-profit organization that focuses on environmental preservation. To overcome the environmental problems in the villages of Sekaralas and Sekarputih, Ngawi, East Java, especially regarding the condition of damage to the forest area and both springs in the village area, Kraton Ngiyom uses communication strategies based on local wisdom by utilizing mythologically oriented instrument and ceremonies as a medium of communication to encourage the public to care and actively contribute in carrying out environmental preservation activities. This study aims to answer the research question of how the Kraton Ngiyom uses myth and rituals as communication strategies for environmental conservation in the villages of Sekaralas and Sekarputih. This study employs an ethnographic study approach. Data collection was carried out using direct observation and in-depth interviews with five informants. The results of this study found that the communication strategies based on local wisdom are well implemented by Kraton Ngiyom through 2 instruments, namely myths and rituals. The myth is used by Kraton Ngiyom to deliver environmental preservation messages to the people of Sekaralas and Sekarputih villages, while the rituals are used by Kraton Ngiyom as instruments to support the delivery of messages, which is to encourage changes in village community behavior. The process of delivering messages through myths, which was maximized in the implementation of a ceremony, succeeded in changing the behavior of Sekaralas and Sekarputih villagers to become more concerned about their environmental conditions and to take initiatives in undertaking environmental conservation efforts.
\end{abstract}

Keywords: Communication Strategy; Kraton Ngiyom; Local Wisdom; Environmental Preservation; Functional Structural Theory; Myth, Ceremony.

\section{Introduction}

Indonesia is known as the largest archipelagic country in the world, with more than 17,000 islands and 1,331 ethnic groups, according to the 2010 census (BPS, 2015). With the widely spread location and large number of ethnic groups, Indonesia has no less than 652 regional languages (Ministry of Education and Culture
Indonesia, 2018). This diversity is a potential capital for the strength of the Indonesian people.

Not only cultural wealth, Indonesia as one of the mega-biodiversity countries in the world is also blessed with a high diversity of natural and non-biological natural resources (LIPI, 2010). Community management and control of natural 
resources are highly important. Yet, in reality Indonesia is currently in an ecological emergency; a precarious situation due to environmental damage (Wahana Lingkungan Hidup Indonesia, 2018). Environmental problems remain as issues that require attention and resolution in Indonesia.

Data from the Directorate of Watershed Management state that of the 318 watersheds spread throughout Indonesia with an area of 3 million hectares, about 2.7 million hectares are in critical condition and heavily damaged, and have not received enough serious attention (Mangkunegara, 2007). The rate of deforestation reaches 1.8 million hectares per year, which is a factor causing other disasters such as floods, soil erosion, drought, and landslides (Ministry of Forestry, 2007). Environmental damage caused by exploitation also occurred in various regions in Indonesia, including in Sekaralas and Sekarputih Villages.

Sekaralas and Sekarputih are villages in the Widodaren District, Ngawi Regency, East Java Province. The two villages used to have areas of mixed forests which were covered with various types of woody trees. Since the looting of forests in 1998, the once-beautiful location has become neglected and also damaged. The environmental conditions in the two villages are quite alarming, motivating the Non-Governmental Organization (NGO) Kraton Ngiyom to take action to overcome this problem.

The effort undertaken by Kraton Ngiyom is to utilize local wisdom as a medium in delivering messages to the people of Sekaralas and Sekarputih villages. This local wisdom is tried to be conveyed through two cultural instruments, namely through the arts of rituals and mythology. Initially, rituals and mythical arts began to be abandoned by the community because they were considered no longer relevant to the demands of the times, however Kraton Ngiyom tried to revive the rituals and myths that once lived in the local community.

A series of mythical narratives were developed to produce the ritual art known as the Kebo Ketan Ceremony, which was first held in 2016. Seeing this phenomenon, the writers want to examine the uses of myth and rituals as communication strategies used by Kraton Ngiyom in building awareness of Sekarlaras and Sekarputih villagers to contribute to the efforts of environmental conservation.

\section{Problem Identification}

Efforts to deliver messages using local wisdom-based communication strategies such as those carried out in the villages of Sekaralas and Sekarputih through the Kebo Ketan Ceremony are rarely found today, because they are considered taboo by the community. However, Kraton Ngiyom succeeded in applying myth and rituals as communication strategy for environmental preservation efforts. The environmental conditions in Sekaralas and Sekarputih villages are increasingly improving due to reforestation, cleaning of water springs and improvement of village infrastructure that have been carried out.

This study seeks to illustrate the implementation of communication strategies based on local wisdom through myths and rituals carried out by the Kraton Ngiyom NGO in carrying out environmental conservation efforts.

\section{Literature Review}

\section{Communication Strategy}

Communication strategy is an action management plan that is arranged to 
achieve certain goals. Communication strategy does not only serve as a guiding direction, but must present an operational tactic in which the approach can change at any time depending on the conditions and situations that occur (Effendy, 2003). Meanwhile, according to Littlemore (2003, p. 1) communication strategies are steps that must be taken in improving the effectiveness of communication.

R. Wayne Pace, Brent D. Paterson, and M. Dallas Burnet in their book Techniques for Effective Communication, as quoted by Effendy (1981), state that there are 3 main objectives of the communication strategy, namely:

1) To secure understanding,

2) To establish acceptance, and

3) To motivate action

To secure understanding means the communicator must be able to ensure that the communicant understands the message received. After understanding and accepting the message, the recipient must be fostered (to establish acceptance), and finally the activities are motivated (to motivate action).

\section{Local Wisdom}

Local wisdom is also known as local knowledge or local genius. Local wisdom, according to Suparmini (2012, p. 11) can be defined as a view of life and knowledge as well as a variety of life strategies in the form of activities carried out by a local community in answering various problems in meeting their life needs. This knowledge can be in the form of norms, values and beliefs that underlie the behavior of a society that is sometimes expressed through myths and traditions.

\section{Myths}

Myth is an element of local wisdom. According to Audifax (2005, p. 8) myth is defined as:

Myth is a story from the past. Myth explains the essence of life and the world, or expresses the existence of cultural moral values in human life. Myth pays attention to the forces that control human life and the relationship between these forces and human existence.

Meanwhile, according to Nurgiyantoro (2010) myths arise and are related to community life that serves to answer various problems that arise. Therefore it can be concluded that myth is something believed by a group of people, its existence serving as a means of control for human behavior, as well as a solution to answer social problems in society. Myth is often associated with the magical or supranatural, and has a sacred value; these are considered true and believed by the community. Besides, myths are also associated with various rituals or processions carried out by the community (Humaeni, 2012).

\section{Ritual}

The ritual is a form of dramatization of a mythical story. A ritual is a structured action considered to be full of meaning and philosophy (Keesing, 1981). Meanwhile, according to Koentjaraningrat (1980, p. 140) "A ritual is a system of activities or sequences or actions arranged by custom or law applicable in a society that is associated with various kinds of fixed events that usually occur in the community concerned." The ritual has a function a medium of integration and social glue for a community group, and functions as a medium for every community member to 
introduce themselves and show their status in the group (Ayatrohaedi, 1986).

\section{Structural Functional Theory}

Structural functional theory, developed by Talcott Parsons, considers that society is incorporated in a social system, which consists of parts or elements that are interconnected with one another so that one part will not function if it is not related to the other parts (Ritzer, 2011).

There are four conditional requirements of a system, called AGIL: Adaptation, Goal Attainment, Integration, and Latency. For the sake of human survival, a system in society must be able to undergo the four functions of AGIL (Ritzer \& Goodman, 2014):

1) Adaptation: A system must be able to understand and overcome situational needs from the outside, not only that, a system must be able to make adjustments to the surrounding environment and adjust the environmental conditions to their needs.

2) Goal attainment: A system must have clear goals, and must be able to achieve these goals.

3) Integration: The components that are in a system must be able to interact, as well as regulate the relationships among parts within it

4) Latency: A system must be able to maintain, complement each other, improve, and update individual motivations and cultural patterns that create and maintain that motivation.

\section{Research Method}

\section{Research Approach}

Research is a systematic process that involves collecting data and analyzing data information scientifically to solve a problem and increase understanding of an event or phenomenon that interests us (Leedy, 1997). In this study, the researchers used a qualitative approach. The qualitative approach according to Creswell $(2012$, p. 4) is:

A type of research in which the researcher is highly dependent on information from the object/participant, having broad scope, general questions, data collection consisting mainly of words/texts from participants, describing and conducting research subjectively.

A qualitative approach is expected to provide a comprehensive, and more in-depth explanation of the behavior, writing and speech that can be observed in a context setting and studied in its entirety (Bogdan \& Taylor, 2010). The statement is in accordance with the purpose of this research, namely, to analyze in depth the local wisdom-based communication strategy carried out by Kraton Ngiyom in environmental preservation efforts in the villages of Sekarputih and Sekaralas.

The research method used in this study is the ethnographic research method. Ethnographic studies are qualitative research procedures for describing, analysing, and interpreting cultural patterns in the form of behaviour, beliefs, and language that form from time to time in a cultural community (Creswell, 2012). Ethnographic research provides a description and provides an explanation of what naturally occurs in the field without any process or action to change it 


\section{Available online di http://ejournal.undip.ac.id/index.php/humanika}

(Hammersley \& Atkinson, 2008). Creswell (2012, p. 90) asserted that "As a process, ethnography involves extensive observation of a group, mostly through participatory observation, in which researchers blend into people's daily lives and observe and interview groups that are the subject of research." The data collection was conducted in this study through semi-structured interview for the purpose of gaining deeper information from selected informants.

\section{Unit of Analysis}

The unit of analysis can be individuals or non-individuals such as communities, groups, and social interactions (Trochim, 2006).

In this study, the unit of analysis examined refers to non-individuals, because the focus of the research will be on Kraton Ngiyom as a non-governmental organization, and how the local wisdombased communication strategies they use can encourage the community to conserve the environment. The participants involved in this study include:

1. Bramantyo Prijosusilo, chair of Kraton Ngiyom NGO

2. Mbah Kodok, a community leader

3. Sulistyono, Chair of the Ngawi Government Arts and Culture Development Division

4. Sihyanto Budi, head of Sekaralas Village

5. Semiarto Aji, an anthropologist

\section{Data Analysis Method}

The data analysis plan is an important stage in a qualitative research. It is an analysis carried out by organizing data, sorting into manageable units, finding new results, searching and finding patterns, and deciding what is told to others (Bogdan \& Biklen, 1982). In conducting data analysis there are 3 stages, namely data reduction, data presentation, and drawing conclusions.

1) Data Reduction: The results of data collection through interviews will be simplified through data reduction, by summarizing the results of the interview, selecting and determining the things that are considered important, and focusing the data on important matters

2) Data Presentation: Presentation of data in research can take the form of brief narratives, tables, and so forth. Data presentation aims to make it easier to understand the problems that occur, and help researchers to decide on an action, so that conclusions can be drawn as soon as possible

3) Drawing Conclusions: Drawing conclusions is the last step that must be done, done by interpreting the data grouping patterns that have been done through the coding process. This conclusion is made by finding patterns drawn through the collected data.

The analysing process was done by classifying and categorising the data that had been collected from the informants. All the data were classified into 3 (three) clusters, namely: Communication Strategies Based on Local Wisdom; Myth as a Medium of Message Delivery; and Rituals as Supporting Instruments to the Message Delivery Process. After being clustered, the data were categorised based on the information gathered from the informants. Lastly, the researcher tried to find the pattern and analysed with the related theory and concepts in order to answer the research problem. 


\section{Results and Discussion}

\section{Communication Strategies Based on Local Wisdom}

Kraton Ngiyom is a non-governmental organization that focuses on environmental, cultural and artistic preservation activities. The formation of the NGO was motivated by two problems, namely concern about the worsening environmental conditions of the Sekaralas and Sekarputih villages, especially the condition of the forest and the two springs in the village area that had been neglected since the massive plundering of the forests in 1997, and the fading cultural values in the 'modern' society, in which the community's awareness of traditional arts is declining.

In promoting the return of art in modern society and restoring the quality of the environment, a role in communication is needed. In order to achieve goals and create an effective communication process, Kraton Ngiyom requires a communication strategy. A communication strategy consists of steps that must be taken in improving the effectiveness of communication (Littlemore, 2003). The communication strategy does not only act as a guiding direction, but must provide an operational tactic where the approach can change according to the conditions and situations that occur (Effendy, 2003). Communication strategies have several goals, one of which is to motivate action (Effendy, 1981). Kraton Ngiyom has several objectives to be achieved, namely encouraging public awareness so that they care, be moved, and contribute to environmental preservation activities, as well as resurrecting traditional arts that are being abandoned by the community.

In planning the communication strategy, Kraton Ngiyom uses a local wisdom-based approach. Local wisdom is defined as a knowledge and life strategy used to answer various problems in people's lives (Suparmini, 2012, p. 11). The problems to be overcome by Kraton Ngiyom are environmental problems that occur in the villages of Sekaralas and Sekarputih. The logged forest, and the neglect of Sendang Margo and Sendang Ngiyom water springs, cause the surrounding villages to experience drought; a problem that requires a solution. A solution is urgently needed, because if the problem is not immediately resolved, it will become a serious problem in the future.

\section{Myth as a Medium of Message Delivery}

Myth is used as an instrument used by Kraton Ngiyom in delivering messages to the public. Myths, according to Nurgiyantoro (2010), are considered to have a fairly close relationship with human life and serve to answer various social problems that arise in social life. There are myths that still have a close relationship to the life sphere of the Sekaralas and Sekarputih villagers, developed and believed by the local community, namely a body of myths about Prabu Brawijaya, the King of Majapahit, who had visited several locations in the Ngawi region. Bramantyo, as chair of Kraton Ngiyom, understands that myths are believed to have magical and mystical powers, the magical and mystical sides are serving to attract the attention of the public so that the messages contained in a mythical story will be more easily digested and absorbed by the community. Every mythical story is always full of myths and messages, so myths are considered to have a function as a means of control to keep humans from unethical and immoral behavior. This is consistent with the explanation of the 
myth according to Audifax (2005, p. 8), stating:

Myth is a story from the past. Myth explains the essence of life and the world, or expresses the existence of cultural moral values in human life. Myth pays attention to the forces that control human life and the relationship between these forces and human existence.

\section{Rituals as Supporting Instruments to the Message Delivery Process}

A ritual is defined as "a system of activities or sequences or actions arranged by custom or law applicable in a society that is associated with various kinds of fixed events that usually occur in the community concerned" (Koentjaraningrat, 1980). To maximize the process of delivering messages, Kraton Ngiyom carried out two forms of ritualistic activities, namely the Wedding of Mbah Kodok and the fairy Setyowati, and the Kebo Ketan Ceremony. The enactment of a ritual is always based on the myth supporting it. Rituals and myths are closely related, in which the ritual is the manifestation of a mythical story, and in practice the ritual plays a role in strengthening the mythical story. If the myth serves to convey a message, the ritual serves to strengthen the story by inviting the public to feel and to be directly involved in a procession.

In every ritual, Kraton Ngiyom always holds various processions, which is done to realize the function of the ritual so that people attending can feel, see and be involved in the whole ritualistic activities. Rituals are also actions that have been structured and are considered to be full of meaning and philosophy (Keesing, 1981). In the Kebo Ketan ritual, the procession of slaughtering the Kebo Ketan is considered to have meaning and philosophy as a form of a slametan celebration to celebrate the work of Kraton Ngiyom with the people, who for the entire year worked together to share their efforts to rehabilitate the village environment, where the slametan celebration is usually synonymous with an animal sacrifice. The ritual has a function as a medium of integration and social glue for a community group, and functions as a medium for every citizen to introduce themselves and show their status in the group (Ayatrohaedi, 1986). This can be seen through the implementation of the Kebo Ketan ritual, where people work together to help ensure the smooth implementation and success of the ritual. The involvement of the village community can be seen through a number of activities carried out, such as cooking large amounts of food for the bancakan (eating together) event carried out jointly and voluntarily by the married women, while the village youths are actively and voluntarily involved in helping to accommodate guests in homestays. Through the Kebo Ketan ritual, the village community became united to gather and cooperate with each other, showing that the ritual became a medium of integration and glue of kinship within the village.

The work of Kraton Ngiyom in carrying out efforts to conserve the environment shows some tangible results that can be seen and felt. Thanks to the hard work and mutual cooperation carried out by Kraton Ngiyom with the community in caring for and improving the environment, the forest area and the two water springs, Sendang Margo and Sendang Ngiyom, succeeded in having a change in land status to a conservation area. The discharge of the Sendang Margo and Sendang Ngiyom springs is now also increasing, with at least 8 liters coming out of the spring per second. In addition, the forest area began to be overgrown with various types of trees. Kraton Ngiyom's local wisdom-based communication strategy in environmental preservation efforts in the Sekaralas and Sekarputih village communities has become an effective communication strategy, because 
it has succeeded in driving changes in village community behavior towards a more positive direction, as well as making a real impact on the environment.

\section{Structural Functional Theory in Adjusting with Social System}

The structural functional theory developed by Talcott Parsons views that society is incorporated in a social system, where each part in a system has a relationship related to one another, and that changes that occur in one part will affect other parts (Ritzer, 2011). In this context, Kraton Ngiyom and the society are part of a social system unity that must always establish cooperative relations for the sake of creating a balance, namely a balance between humans, nature, and culture.

In structural functional theory, there are four absolute conditions that must be fulfilled by a system. The four conditions are referred to as AGIL, which stands for Adaptation, Goal Attainment, Integration, and Latency. A system in society must be able to carry out these four AGIL functions (Ritzer \& Goodman, 2014):

1) Adaptation: A system must be able to make adjustments to the surrounding environment and adjust the environmental conditions to their needs. In the function and process of adaptation, Bramantyo, as chair of Kraton Ngiyom NGO, tried to study the social conditions and characteristics of the surrounding environment, and to observe what values might still be held firmly by the community before designing a communication strategy. The values referred to here are the values of tradition and culture. The results of the observation show that in the scope of daily life, Sekaralas and Sekarputih villagers still believe in and uphold the mythical story about Prabu Brawijaya, and the village community still performs a number of rituals such as cleaning the village and jembulan ritual. The community's belief in these two things forms the basis of the idea of Kraton Ngiyom to make myths and rituals as a medium for delivering messages to the public.

2) Goal attainment: A system must have goals and must be able to achieve these goals. Kraton Ngiyom as an institution has a goal to be achieved, which is to encourage public awareness so that they care, be moved and contribute to environmental preservation activities, as well as resurrecting traditional arts which are gradually being abandoned and considered unattractive. These two objectives were motivated by the concern of Kraton Ngiyom NGO to see the increasingly worsening environmental conditions of Sekaralas and Sekarputih villages, especially the condition of the forest and the two neglected springs, Sendang Margo and Sendang Ngiyom, and the fading cultural values in the scope of public life. To achieve these goals, Kraton Ngiyom uses a communication strategy based on local wisdom to encourage awareness and change people's behavior. The way to do this is to make a reconstruction of myths carried out with the aim of conveying the message to the public, as well as carrying out a ritualistic art activity in order to maximize the process of delivering the message.

3) Integration: The components within a system must be able to interact, as well as regulate the relationships between parts within. Interactions that occur between Kraton Ngiyom and the community occur when communicating a mythical narrative to 
the public. The process of conveying this myth is done verbally, so that there is a direct interaction between the communicator and the recipient of the message. In addition, the process of interaction also occurs during a ritual activity. In every ritual carried out by Kraton Ngiyom, the role of community involvement becomes a very important component.

4) Latency: The system must be able to understand, maintain, improve, and renew, both individual motivation and cultural patterns. Maintenance of communication patterns carried out by Kraton Ngiyom with the community is carried out by developing and updating the mythical narratives.

Development and renewal of the mythical narratives can later be adjusted to the problems that arise in the lives of the public, the message to be conveyed can also be adjusted to the urgency of the problem that would require a solution, as well as what effect it wants to achieve. The development of the myths, as well as making them alive, are carried out by Kraton Ngiyom with the aim that the myths remain functional in society, and can become solutions to societal problems.

\section{Conclusions}

The communication strategy based on local wisdom is implemented by Kraton Ngiyom through 2 instruments of local wisdom, namely myths and rituals. The myths are used by Kraton Ngiyom to deliver environmental preservation messages to the people of Sekaralas and Sekarputih villages, while the rituals are used by Kraton Ngiyom as instruments to support the delivery of messages, which is to encourage changes in village community behavior.

Kraton Ngiyom, through its communication approach, succeeded in encouraging changes in the behavior of the village communities in carrying out environmental rehabilitation activities.

The work of Kraton Ngiyom and the contributions of Sekaralas and Sekarputih villagers made Sendang Margo and Sendang Ngiyom as well as the forest area in Sekaralas village receive a status of conservation area from Perhutani in 2016.

\section{References}

Audifax. (2005). Mite Harry Potter: Psikosemiotika dan Misteri Simbol di Balik Kisah Harry Potter. Yogyakarta: Jalasutra.

Ayatrohaedi. (1986). Kepribadian Budaya Bangsa (local Genius). Jakarta: Dunia Pustaka Jaya.

Bogdan, R. C., \& Biklen. (1982). Qualitative Research for Education: An Introduction to Theory and Methods. London: Allyn and Bacon, Inc.

Bogdan, R. C., \& Taylor. (2010). Metodologi Penelitian Kualitatif. Bandung: Remadja Karya.

BPS. (2015). Mengulik Data Suku di Indonesia. Retrieved October 8, 2019, from https://www.bps.go.id/news/2015 /11/18/127/mengulik-data-suku- diindonesia.html

Creswell, J. W. (2012). Research Design Pendekatan Kualitatif, Kuantitatif dan Mixed. Yogyakarta: Pustaka Pelajar.

Effendy, O. U. (1981). Dimensi-Dimensi Komunikasi. Bandung: PT Rosdakarya.

Effendy, O. U. (2003). Ilmu, Teori dan Filsafat Komunikasi. Bandung: Citra Aditya.

Hammersley, M., \& Atkinson, P. (2008). Ethnography, principles in practice 
(3rd ed.). London: Taylor \& Francis.

Humaeni, A. (2012). The Local Tradition of Magical Practices in Banten Society. EL HARAKAH: Jurnal Budaya Islam, 14(1), 69-87.

Keesing, M. R. (1981). Antropologi Budaya: Suatu Prespektif Kontemporer. Jakarta: Erlangga.

Koentjaraningrat. (1980). Sejarah Teori Antropologi. Jakarta: Universitas Indonesia Press.

Leedy. (1997). Practical Research: Planing and Design. New Jersey: Merrill Prentice Hall.

LIPI. (2010). Indonesia Negara Biodiversity di Dunia. Retrieved October 6, 2019, from

http://lipi.go.id/berita/indonesianegara-mega-biodiversity-di-dunia$/ 5181$

Littlemore, J. (2003). The communicative effectiveness of different types of communication strategy. System, 31(3), 331-347.

Mangkunegara, A. A. A. P. (2007). Manajemen Sumber Daya Manusia Perusahaan. Bandung: PT. Remaja Rosdakarya.

Ministry of Education and Culture Indonesia. (2018). Badan Bahasa Petakan 652 Bahasa Daerah di
Indonesia. Retrieved December 2, 2020, from https://www.kemdikbud.go.id/main/ blog/2018/07/badan-bahasapetakan-652-bahasa-daerah-diindonesia

Ministry of Forestry. (2007). Deforestasi Indonesia Tahun 2007. Jakarta: Kementerian Kehutanan.

Nurgiyantoro, B. (2010). Penilaian Pembelajaran Bahasa. Yogyakarta: BPFE.

Ritzer, G. D. J. (2011). Teori Sosiologi Modern. Jakarta: Prenada Media Group.

Ritzer, G. D. J., \& Goodman, D. J. (2014). Teori Sosiologi. Yogyakarta: Kreasi Wacana.

Suparmini. (2012). Modul Pola Keruangan Desa dan Kota. Yogyakarta: Lembaga Penelitian dan Pengabdian Masyarakat Universitas Negeri Yogyakarta.

Trochim, W. M. K. (2006). Social Research Methods: Non-Probability Sampling. Retrieved December 3, 2020, from http://www.socialresearchmethods.n et/kb/sampnon.php

Wahana Lingkungan Hidup Indonesia. (2018). Tinjauan Lingkungan. 